\title{
Community Shift of Methane-oxidizing Bacteria in Cover Soil of Waste Landfills Due to Methane Emission
}

\author{
Tomonori Ishigaki (Corresponding author) \\ Center for Material Cycles and Waste Management Research, National Institute for Environmental Studies, 16-2 \\ Onogawa, Tsukuba \\ Ibaraki 305-8506, Japan \\ Tel: 81-29-650-2389 E-mail: ishigaki@nies.go.jp
}

Hiromi Sawamura

Department of Civil Engineering, Fukuoka University, 8-19-1, Nanakuma, Jonan, Fukuoka 814-0180, Japan

Kaoru Ikeda

Department of Environmental Solution Technology, Faculty of Science and Technology, Ryukoku University

1-5, Yokotani, Seta-Oe

Otsu, Shiga 520-2194, Japan

Masato Yamada

Center for Material Cycles and Waste Management Research, National Institute for Environmental Studies, 16-2

Onogawa, Tsukuba

Ibaraki 305-8506, Japan

Received: December 18, $2011 \quad$ Accepted: December 22, $2010 \quad$ Published: January 1, 2012

doi:10.5539/ep.v1n1p75

URL: http://dx.doi.org/10.5539/ep.v1n1p75

This study was financially supported by the Environment Research and Technology Development Fund (A1001) from Ministry of Environment, Japan

\begin{abstract}
Methane oxidation at landfill surfaces was characterized using both physiological and genetically -based assessments of bacterial community. Two different types of methane oxidation were observed, depended on one of which involved separate methane-oxidizing reaction that were dependent on the initial methane concentration, and the other one involved normal Michaelis-Menten type kinetics. The MOB community structure was assayed by culture-independent molecular microbiological methods. The gene amplified by pmoA primer, as a measure of the total MOB population, was detected in levels of $10^{4}$ to $10^{5} \mathrm{MPN}$-copies $\cdot \mathrm{g}^{-1}$, and accounted for $2.9 \%$ $49 \%$ of the eubacterial $16 \mathrm{~S}$ rDNA. In soils exposed to high methane flux, the type II MOB was predominated showing the value of $10^{4} \mathrm{MPN}$-copies $\mathrm{g}^{-1}$ of the $\mathrm{mmoX}$ gene and amounted to 30-90\% of the corresponding pmoA gene copies detected. In contrast, type I MOB existed in relatively high population at soils under the negative/negligible methane flux.
\end{abstract}

Keywords: Methane oxidation, Methane-oxidizing bacteria, Waste landfill, Cover soil, MPN-PCR

\section{Introduction}

The attribution of global climate changes to emissions of greenhouse gas (GHG), including carbon dioxide, methane, and nitrogen oxide, has gained intensive public attention. Methane is one of the most important GHGs, because its global warming potential is estimated to be more than twenty times of that of carbon dioxide and 
because atmospheric methane has increased by $1 \%$ per year in recent decades (Blake, 1988). Waste landfills have been recognized as a large source of anthropogenic methane emission and as an important contributor to global warming (IPCC, 1994). Since methane emission from waste landfills is estimated to account for 3-19 \% of the anthropogenic emission of methane worldwide (IPCC, 1994), the importance of monitoring and countermeasures against methane emission from waste landfills needs to be recognized. In waste landfills, methane is generated in layers of waste as a terminal product of the anaerobic biodegradation of organics. Microbial methane oxidation, which occurs only at the surface layers, is carried out by obligate aerobic methane-oxidizing bacteria (MOB), which provide the only terrestrial sink of methane in waste landfills. MOBs oxidize methane with oxygen and utilize it as carbon and energy sources (Bowman, 1994; Hanson \& Hanson, 1996). The first step in the methane oxidizing process is catalyzed by the enzyme methane monooxygenase, of which two forms are known; the particulate methane monooxygenase (pMMO), a membrane-bound enzyme present in all MOB examined to date, and the soluble methane monooxygenase (sMMO), a cytoplasmic enzyme present only in certain species. In addition, MOBs are classified as either type I or II according to the carbon assimilating pathway, the intracytoplasmic membrane arrangement, the presence of complete tricarboxylic cycles, and the type of membrane phospholipid fatty acids (Tsien et al., 1990). Furthermore, the type II MOB, which belongs to the $\alpha$-subdivision of the phylum Proteobacteria, possesses pMMO and sMMO, whereas the type I MOB, which belongs to the $\gamma$-subdivision of the phylum Proteobacteria, generally possesses only pMMO, except of a few unusual genera such as Methylococcus (Koh et al., 1993; Shigematsu et al., 1999). It has been widely known that pMMO is phylogenetically similar to ammonia monooxidase (AMO), and its substrate specificity is also low; i.e. ammonium oxidizing bacteria that possess AMO are capable for oxidizing methane (Bedard \& Knowles, 1989). Amaral \& Knowles (1995) reported that type I and II MOB show an apparent prevalence to the availability of oxygen and methane, respectively. The type I MOB generally dominate in layers with low methane and high oxygen concentrations, whereas the type II MOB favor high methane and low oxygen concentrations (Amaral \& Knowles, 1995; Amaral et al., 1995). In general, little is known about the MOB community structure in soil, but type II MOB has been found more frequently than the type I MOB (Hanson \& Hanson, 1996; Henckel et al., 1999) in certain areas such as in tundra soils (Vecherskaya et al., 1993), peat land soils (Sundh et al., 1995), and soils in Alaska (Brusseau et al., 1994). On the other hand, the type I MOB has been shown to dominate in aquatic environments such as lake water (Hanson \& Hanson, 1996, Ross et al., 1997) and lake sediment (Boschker et al., 1998, Auman \& Lidstrom, 2002) both types of MOB have been found in rice fields (Henckel et al., 1999; Horz et al., 2001).

In contrast to the focus on MOB found in natural environments, less attention has been paid to the characterization of MOB communities found in landfill surface layers. Bogner et al. (1997) reported the presence of at least two groups that showed different methane oxidation kinetics in the cover soil of landfill surfaces. Wise et al. (1999) revealed that both type I and II MOB were detected at landfill surfaces, and the type II MOB were much more diverse than the type I MOB. However, not much is known about the community structure and population dynamics of MOB at landfill surfaces, and the environmental factors affecting MOB communities remain unidentified. The characteristics of landfills, including the methane emission, dynamically changed during the several decades of management (Pohland \& Al-Yousfi, 1994), and these changes have strongly affected the methane oxidizing activity and MOB communities living at landfill surfaces. In order to estimate the function of waste landfills as source and sink of methane emission, it will be necessary to characterize MOB activity and community structure.

In this study, methane oxidation in landfill surface soils exposed to different methane concentrations was characterized using both physiological and genetically based microbiological methods. The methane oxidizing capacity of the soil was quantitatively evaluated and the rate constants were estimated. The community structure of MOB was assayed by a culture-independent molecular microbiological method. In these soils, some bacterial groups were monitored by genetic quantification. The total Eubacteria amount was monitored by the quantification of eubacterial 16S ribosomal RNA gene (rDNA), and the total MOB amount was monitored by quantification of the $p m o A$ gene, which encodes the $\alpha$ subunit of the pMMO and is included in most of MOBs (Balasobramanian \& Rosenzweig, 2007). Type I MOB was monitored by quantification of the type I MOB-specific 16S rDNA. The $m m o X$ gene which encodes the $\alpha$ subunit of the hydroxylase component of sMMO were also subjected to monitor as a representative indicator of the well-known type II MOBs, though recently some type I Methylomonas strains were founded to possess genes for sMMO exceptionally (Auman \& Lidstrom, 2002). Then, the kinetics of certain MOB strains isolated from soil samples were characterized, and the results were compared with those from a DNA-based community analysis. The relationships between methane emission, methane-oxidizing activity, and MOB community structure at landfill surfaces are discussed. 


\section{Materials and Methods}

\section{1 Methane Flux Measurement and Soil Sampling}

The measurement of surface methane flux was carried out by the static chamber method as described previously (Ishigaki et al., 2005). Two already-closed landfills located in Japan were subjected to flux measurement and soil sampling. Surface methane flux was measured at 40 points on the each surface, and six points were selected based on the flux (positive, negative and not detected) as targets of the MOBs community analysis. Measuring points A-D were on the surface of a landfill that had been closed for 2 years; that landfill contained industrial waste such as organic sludge, textiles, wood, plastics, incinerated residue, slag, and other materials. Points $\mathrm{E}$ and F were on the surface of a landfill that had been closed for 15 years, and that landfill also contained industrial waste such as incinerated residue, plastics, slag, and other materials. The experimental surfaces of these landfills were tentatively covered by approximately $50 \mathrm{~cm}$ of sandy soil which was mainly composed of coarse sand. General characteristics of these soils were shown in Table 1. The concentrations of methane and carbon dioxide were measured using a gas chromatograph GC8A (Shimadzu Co., Kyoto, Japan) equipped with a flame ionization detector and a Porapak Q column. At the selected point from the flux measurement, soil samples were taken at $5-10 \mathrm{~cm}$ depth and were used for the physiological and genetic characterizations of the methane oxidizing communities.

\subsection{Methane Oxidation Kinetics of Soil Samples}

Five hundred milligrams of soil were added to a 30-ml test tube capped with a butyl septum, to which was added $9.5 \mathrm{ml}$ of basal medium $\left(\mathrm{MgSO}_{4} \cdot 7 \mathrm{H}_{2} \mathrm{O}: 630 \mathrm{mg} \cdot \mathrm{l}^{-1}, \mathrm{CaCl}_{2} \cdot 2 \mathrm{H}_{2} \mathrm{O}: 90 \mathrm{mg} \cdot \mathrm{l}^{-1}, \mathrm{KNO}_{3}: 450 \mathrm{mg} \cdot \mathrm{l}^{-1}, \mathrm{NaHPO}_{4}: 1.5\right.$ $\mathrm{mg} \cdot \mathrm{l}^{-1}, \mathrm{FeSO}_{4} \cdot 7 \mathrm{H}_{2} \mathrm{O}: 12 \mathrm{mg} \cdot \mathrm{l}^{-1}, \mathrm{MnSO}_{4} \cdot 5 \mathrm{H}_{2} \mathrm{O}: 5.6 \mathrm{mg} \cdot 1^{-1}, \mathrm{CoCl}_{2} \bullet 6 \mathrm{H}_{2} \mathrm{O}: 1.0 \mathrm{mg} \cdot \mathrm{l}^{-1}$, Soil extracts.: $\left.19 \mu \mathrm{l}\right)$. Methane was added into the headspace of the test tube as final concentrations of $50-100,000 \mathrm{ul}^{-1} 1^{-1}$, and each test tube was incubated at $28{ }^{\circ} \mathrm{C}, 120 \mathrm{rpm}$. The headspace gas of the test tube was diluted by the addition of methane; the initial oxygen concentration in the headspace ranged between approximately $18 \%-20 \%$ according to the amount of methane that had been added. All experiments were triplicated and the methane oxidizing activity was estimated by linear decrease of the headspace methane concentration. The maximum methane oxidation rate $\left(\mathrm{V}_{\mathrm{m}}\right)$ and the affinity of methane (apparent $\mathrm{K}_{\mathrm{s}}$ ) were determined by the Michaelis-Menten equation as follows

$$
\frac{d S}{d t}=\frac{V_{m} \cdot S}{K_{S}+S}
$$

where $\mathrm{S}$ is the methane concentration. Michaelis constants were estimated according to the 4th order Runge-Kutta method using the simulation program Berkeley MADONNA for Windows (Hannon \& Ruth, 1997).

\subsection{Isolation of $M O B$ Strains and Methane Oxidation Test}

One gram of soil sample suspended in $99 \mathrm{ml}$ of sterile deionized water was plated onto an agar-basal media, and the bacteria were cultivated in a chamber containing $1.0 \%$ methane at $35{ }^{\circ} \mathrm{C}$ for 28 days. Colonies morphologically identified as representing a single type of cell were isolated as candidate MOB strains. Candidates that exhibited significant methane oxidation were selected as MOB strains by repeated cultivations. The methane oxidation test of MOB isolate was carried out as well as that of soils; all the difference was the addition of $0.5 \mathrm{ml}$ of the MOB pre-culture instead of the addition of $500 \mathrm{mg}$ of the soil. The first-order kinetics was calculated by linear regression of the methane oxidation rate against the initial methane concentration $\left(50-100,000 \mathrm{ul} \cdot \mathrm{l}^{-1}\right)$. For the isolates that followed Michaelis-Menten kinetics, pseudo-firstorder rate constants were estimated as $\mathrm{V}_{\mathrm{m}} / \mathrm{K}_{\mathrm{s}}$. The cell number of each strain was estimated from the ATP concentration using the ATP analyzer AF-100 (DKK-TOA Co., Tokyo, Japan)

\subsection{DNA Extraction}

DNA was extracted and purified directly from the landfill surface soil by using the FastDNA SPIN kit for Soil (BIO101, Carlsbad, CA) according to the manufacturers instruction. The resultant DNA was purified and concentrated by Amicon Microcon PCR (Nihon Millipore Co. Ltd. Tokyo, Japan).

\subsection{Quantification of pmoA, mmoX, and Type I MOB-and Eubacteria-specific $16 \mathrm{~S}$ rDNA}

The primer sets used in this study are listed in Table 1. The primer pair for $p m o A$ was used as measure of the total MOB though this primer pair also amplifies amoA that encodes $\alpha$-subunit of AMO. Since AMO is also capable for oxidizing methane, the genes detected using $\mathrm{pmoA}$ primers represent the most of bacteria concerning with methane oxidation (type I and II MOBs and AOB). Genes measuring type I and II MOBs were targeted by the primer pairs for the type I specific 16S rDNA (Holmes et al., 1995) and mmoX (McDonald et al., 1995), 
respectively. The reaction mixture contained 1-5 ng of extracted DNA, $2 \mu \mathrm{l}$ of $10 \mathrm{x}$ Taq Gold buffer, each primer at a concentration of $0.2 \mu \mathrm{M}, 2.0 \mathrm{U}$ of AmpliTaq Gold DNA polymerase, each deoxynucleoside triphosphate at a concentration of $100 \mathrm{mM}$, and 2.5 to $3.5 \mathrm{mM}$ of $\mathrm{MgCl}_{2}$. Amplification was performed in a total volume of $20 \mu \mathrm{l}$ in a $200 \mathrm{ml}$ reaction tube using a Mastercycler Gradient (Eppendorf Japan, Co. Ltd., Tokyo Japan). Amplifications were initiated by the activation of AmpliTaq Gold DNA polymerase for 15 min at $95{ }^{\circ} \mathrm{C}$, and the thermal cycle profile consisted of an initial denaturation for 3 min at $95{ }^{\circ} \mathrm{C}$, followed by $32-35$ cycles consisting of denaturation for $1 \mathrm{~min}$ at $94{ }^{\circ} \mathrm{C}$, primer annealing for $1 \mathrm{~min}$ at the annealing temperature indicated in Table 1 , and elongation for $2 \mathrm{~min}$ at $72{ }^{\circ} \mathrm{C}$. The final elongation period was $5 \mathrm{~min}$. The abundance of each gene in the DNA samples was estimated by most probable number (MPN)-PCR (Picard et al., 1992) by analyzing three replicate sample dilutions.

\section{Results}

\subsection{Methane Flux Rate and Methane Oxidation}

The methane and carbon dioxide flux at several points on the landfill surface are shown in Table 2. Methane flux densities largely fluctuated within the range of $-5.2 \times 10^{-3}$ to $19 \mathrm{mmol}-\mathrm{CH}_{4} \cdot \mathrm{min}^{-1} \cdot \mathrm{m}^{-2}$. Positive methane fluxes were observed at points $\mathrm{A}, \mathrm{C}$ and $\mathrm{E}$. At points $\mathrm{A}$ and $\mathrm{C}$, the methane flux was comparatively higher than that of carbon dioxide, although point $\mathrm{E}$ showed similar values for both fluxes. Negative methane fluxes were observed at points $\mathrm{B}$ and $\mathrm{D}$. The carbon dioxide flux was also low in these soils, but it was relatively high compared to the absolute value of the methane flux. Both the methane and the carbon dioxide flux went undetected at point $\mathrm{F}$ due to low gas emission. The methane oxidizing activities at an initial concentration of $100,000 \mathrm{ul} \cdot \cdot^{-1}$ and $1,000 \mathrm{ul} \cdot l^{-1}$, and the kinetic constants for the methane oxidation are also available in Table 2. In soils A, C and E, separate kinetic trends emerged for low $\left(<1,000 \mathrm{ul} \cdot \cdot^{-1}\right)$ and high $\left(>5,000 \mathrm{ul} \cdot l^{-1}\right)$ initial methane concentrations. These soils exhibited an apparent low-affinity (high $\mathrm{K}_{\mathrm{s}}$ ) at the experiment under the high methane concentration range $\left(>5,000 \mathrm{ul} \cdot \mathrm{l}^{-1}\right)$. Methane oxidation in soils B and D followed the Michaelis-Menten equation throughout the tested concentration range. Furthermore, the $\mathrm{V}_{\mathrm{m}}$ of the methane oxidation and the methane oxidizing activity were 1-2 orders of magnitude higher than those of other soils. Methane-oxidizing activity was detected in soil F, which exhibited no gas flux.

\subsection{Development of MPN-PCR Assays for MOB-Related Genes}

The MPN-PCR assays were validated using known concentrations of standard DNA extracted from Methylosinus trichosporium OB3b (NCIMB11131), which was used as a representative type II MOB, and Methylomonas methanica (NCIMB11130), which was used as a representative type I MOB. The linear range of detection for the MPN-PCR assays for eubacterial 16S rDNA, pmoA and type I MOB specific 16S rDNA were at least 5 orders of magnitude from $2.5 \times 10^{2}-5 \times 10^{6}$ copies' $\mathrm{g}^{-1}$ (Figure 1). On the other hand, the linear range of $\mathrm{mmoX}$ was narrower than those of other genes, and was 4 orders of magnitude from $8 \times 10^{2}-1 \times 10^{5}$ copies $\cdot \mathrm{g}^{-1}$. The regression coefficient values for standard curves for all MPN-PCR assays exceeded 0.9.

\subsection{Estimation of MOB-Related Genes by MPN-PCR}

The results of the MPN-PCR analysis of nucleic acids extracted from the soils with primer sets of Eubacteria-specific 16S rDNA, pmoA, the type I MOB-specific $16 \mathrm{~S}$ rDNA, and $m m o X$ are shown in Figure 2. The eubacterial 16S rDNA existed in abundance at $10^{5}$ to $10^{6} \mathrm{MPN}$-copies $\cdot \mathrm{g}^{-1}$ in each soil sample. The gene amplified by pmoA primers, as a measure of the total MOB population, was detected in levels of $10^{4}$ to $10^{5}$ MPN-copies $\cdot \mathrm{g}^{-1}$, and it was accounted for $2.9 \%$ (soil D) - $49 \%$ (soil B) of the eubacterial $16 \mathrm{~S}$ rDNA. In soils A, $\mathrm{C}$, and $\mathrm{E}$, the high abundance of the $m m o X$ gene was observed where $10^{4}$ MPN-copies $\mathrm{g}^{-1}$ of the $m m o X$ gene amounted to $30-90 \%$ of the corresponding pmoA gene. Type I-specific $16 \mathrm{~S}$ rDNA was detected at levels that were 1-3 orders of magnitude lower than those of the $m m o X$ gene in these soils. Both the $m m o X$ gene and the type I specific $16 \mathrm{~S}$ rDNA were detected within the same range from soil $\mathrm{B}$, in which the gene amplified by pmoA primers comprised a major part of the eubacterial $16 \mathrm{~S}$ rDNA. In soils D and F, the copy number of the type I specific $16 \mathrm{~S}$ rDNA accounted for $51 \%$ and $79 \%$ of that of the $p m o A$ gene, although $m m o X$ was detected at rate less than $20 \%$ of that of $p m o A$. Therefore the type I MOB is thought to account for a major portion of the MOB community in these soils.

\subsection{Physiological Characteristics of MOB Isolates}

Table 3 shows the kinetic constants of methane oxidation by the MOB strains successfully isolated from soils A to D. Methane oxidation by $70 \%$ of all isolates (23 of 33 strains) followed Michaelis-Menten kinetics. In particular, strains AH522, BH502, BH514, BX531, CL104 and strains isolated from soil D (DH501, DH502, DH519., DH521, DH522) exhibited relatively high-affinity (less than $1000 \mu \mathrm{M}$ of $\mathrm{K}_{\mathrm{s}}$ ) for methane. On the other 
hand, most of the isolates from soil $\mathrm{C}$ exhibited low affinity for methane. Methane oxidation by some of the strains ( 2 of 4 strains from soil A, 4 of 10 strains from soil B, and 4 of 12 strains from soil C) followed first-order reaction kinetics at the experimental concentrations. It must be considered that these strains would possess relatively low affinity for methane.

\section{Discussion}

In landfill surface soils $\mathrm{A}, \mathrm{C}$, and $\mathrm{E}$ showing high methane flux, separate kinetic trends emerged for low and high initial concentrations of methane. Bogner et al. (1997) have also reported different methane oxidation kinetics in the low $(<160 \mathrm{ppmv})$ and high $(>10,000 \mathrm{ppmv})$ concentration range in landfill cover soil that exhibited negative methane flux. They concluded that at least two MOB groups, methane-limited and oxygen-limited methanotrophs coexisted at the landfill surface. The present study also suggested that the MOB community would shift to favor high methane concentrations under high methane flux conditions. The methane-oxidizing activities of soils A, C, and E were a few orders of magnitude lower than those of soils B and D. Methane oxidation by soils B, D and F, which showed negative or negligible methane flux, followed Michaelis-Menten equation kinetics. These results indicated that the MOB community structure and function as a methane sink at the landfill surface is strongly influenced by changes in methane emission throughout landfill surface layers.

The gene amplified by pmoA primer pair included both $p m o A$ and amoA that encode $\alpha$-subunit of pMMO and $\alpha$-subunit of AMO (Horz et al., 2001), respectively. Both enzymes are able to oxidize methane; therefore the gene amplified by $p m o A$ primer could be a measure of the gene capable for oxidizing methane. In soils $\mathrm{A}, \mathrm{C}$, and $\mathrm{E}$, the copy number of $m m o X$ gene was highly composed in the number of gene that was estimated by pmo $A$ primer pair. Because the copy numbers of each gene in these cells differ, these results are only of comparative significance. However, normally it was reported that average copy number of $p m o A$ and $m m o X$ genes were contained two and one copies/cell, respectively (Koschorreck et al., 2003, Rahman et al., 2011, Auman \& Lidstrom, 2002). It possibly indicated that a predominance of $m m o X$ - possessing type II MOB in the MOB community in the soils A, C, and E. Amaral et al. (1995) reported that the type I MOB generally favored low methane and high oxygen concentrations, whereas the type II MOB favored high methane and low oxygen concentrations. At the initial phase of landfill stabilization, landfill surfaces are usually exposed to high concentrations of methane due to active waste degradation (Williams, 1998). The high detection of $m m o X$ gene also linked to exposure to high methane concentrations; these soils might be in the initial phase of active methane generation in the long-term degradation process in the waste landfill. This conclusion is supported by the physiological analysis, i.e., a low affinity of the soils for methane and a high abundance of isolates favoring a high concentration of methane.

The MOB community in soil B comprised a major portion of the eubacterial community. Furthermore, type I-specific $16 \mathrm{~S}$ rDNA and $m m o X$ gene were detected in the same order of $10^{4}$ copies $\cdot \mathrm{g}^{-1}$. These results suggested the coexistence of both types of MOB in soil B. The negative flux and high methane oxidizing activity in soil B can be ascribed to the enrichment of highly active MOB in terms of methane oxidation. After the phase involving active methane generation, methane emissions would begin to decrease due to the exhaustion of organic materials, and then the conditions in the cover soil layer would be partially but dramatically different from the initial conditions. The results obtained here suggest that the MOB communities changed in a successive manner, depending on the methane concentration at the landfill surface.

The MOB community in soil $\mathrm{D}$, which also showed a negative methane flux, was clearly different from that in soil $\mathrm{B}$ in terms of the high ratio of type I-specific $16 \mathrm{~S}$ rDNA to pmoA and isolates possessing high affinity but low oxidizing activity for methane. The type I MOB must predominate in MOB community in soil D, and the MOB community itself would not consist a large group in the eubacterial community. It indicated that the behavior of methane emission must be important indicator for the landfill stabilization, but the MOB community analysis also complemented the determination of the stage of the landfill stabilization. In soils such as soil $\mathrm{F}$ with less methane availability, the methane-oxidizing activity and MOB population would also low. Deactivation and decrease of MOB community in the landfill surface soil will nearly close to the fully convergence of LFG emission, which is almost impossible to evaluate by the LFG emission itself since the change of the emission behavior must be little.

These results clearly demonstrated that dynamic changes in waste landfill characteristics strongly influence the activity and the community structure of MOB at landfill surfaces. Two different types of methane oxidation were observed, one of which involved separate methane-oxidizing reaction that depend on the initial methane concentration, and the other type of oxidation involved normal Michaelis-Menten type kinetics. MOB community at landfill surfaces exposed to high concentrations of methane would shift to favor the high 
concentration of methane. In the soils exposed to high methane flux, the abundance of the type II MOB in the community of MOBs was suggested since $10^{4}$ MPN-copies $\mathrm{g}^{-1}$ of the $m m o X$ gene amounted to $30-90 \%$ of the corresponding $p m o A$ gene copies detected. On the other hand, the soils that showed negative/negligible methane flux was divided into two different pattern of MOB community. The soil expected the high methane oxidation showed the coexistence of type I MOB specific and $m m o X$ gene though the type I MOB dominated in the soils with low availability of methane. The isolation and physiological characterization of MOB strains also supported the results of the genetic analysis of the MOB communities. It is likely that MOB communities and the resultant methane-oxidizing activity at the landfill surface are unstable and change in response to long-term variations in waste landfill characteristics. Difference of MOB community by the methane emission behavior will strongly indicate that methane oxidation in landfill surface is not stable. This dynamic change of MOBs community will also affect the evaluation of methane emission including both source and sink. Furthermore, microbial descriptions such as MOBs community in this study could be a candidate for one of indicator of the stabilization of waste landfills.

\section{References}

Amaral, J.A., \& Knowles R. (1995). Growth of methanotrophs in methane and oxygen counter gradients. FEMS Microbiology Letters, 126, 215-220. http://dx.doi.org/10.1111/j.1574-6968.1995.tb07421.x

Amaral, J.A., Archambault, C, Richards, S.R., \& Knowles, R. (1995). Denitrification associated with group I and II methanotrophs in a gradient enrichment system. FEMS Microbiology Ecology, 18, 289-298. http://dx.doi.org/10.1111/j.1574-6941.1995.tb00185.x

Auman, A.J., \& Lidstrom, M.E. (2002). Analysis of sMMO-cintaining Type I methenotrophs in Lake $\begin{array}{lllll}\text { Washington sediment. } & \text { Environmental } & \text { Microbiology, } & \text { 517-524. }\end{array}$ http://dx.doi.org/10.1046/j.1462-2920.2002.00323.x

Balasobramanian, R., \& Rosenzweig, A.C. (2007). Structural and mechanistic insights into methane oxidation by particulate methane monooxygenase. Accounts of Chemical Research, 40, 573-580. http://dx.doi.org/10.1021/ar700004s

Bedard, C., \& Knowles, R. (1989). Physiology, biochemistry, and specific inhibitors of $\mathrm{CH}_{4}, \mathrm{NH}_{4}{ }^{+}$, and $\mathrm{CO}$ oxidation by methanotrophs and nitrifiers. Microbiological Reviews, 53, 68-84.

Blake, D.R. (1988). Continuing worldwide increase in tropospheric methane. Science, 239, 1129-1131. http://dx.doi.org/10.1126/science.239.4844.1129

Bogner, J.E., Spokas, K.A., \& Burton, E.A. (1997). Kinetics of methane oxidation in a landfill cover soil: temporal variations, a whole-landfill oxidation experiment, and modeling of net $\mathrm{CH}_{4}$ emissions. Environmental Science \& Technology, 31, 2504-2513. http://dx.doi.org/10.1021/es960909a

Boschker, H.T.S., Nold, SC., Wellsbury, P., Bos, D., DeGraaf, W., Pel, R., Parkes, R.J., \& Cappenberg, T.E. (1998). Direct linking of microbial populations to specific biogeochemical processes by 13C-labelling of biomarkers. Nature, 392, 801-805. http://dx.doi.org/10.1038/33900

Bowman, J.P. (1994). The methanotrophs- the families Methylococcaceae and Methylocystaceae. In: Dworkin, M. (Ed) the Prokaryotes. [online] Springer Verlag, NY, http:// link.springer-ny.com

Brusseau, G.A., Bulygina, E.S., \& Hanson, R.S. (1994). Phylogenetic analysis of and development of probes for differentiating methylotrophic bacteria. Applied and Environmental Microbiology, 60, 626-636.

Hannon, B., \& Ruth, M. (1997). Modeling dynamic biological systems. Springer-Verlag, New York.

Hanson, R.S., \& Hanson, T.E. (1996). Methanotrophic bacteria. Microbiological Reviews, 60, 439-471.

Henckel, T., Friedrich, M., \& Conrad, R. (1999). Molecular analysis of the methane-oxidizing microbial community in rice field soil by targeting the genes of the $16 \mathrm{~S}$ rRNA, Particulate methane monooxygenase, and methanol dehydrogenase. Applied and Environmental Microbiology, 65, 1980-1990.

Holmes, A.J., Costello, A., Lidstrom, E., \& Murrell, J.C. (1995). Evidence that particulate methane monooxygenase and ammonium monooxygenase may be evolutionarily related. FEMS Microbiology Letters, 132, 203-208. http://dx.doi.org/10.1111/j.1574-6968.1995.tb07834.x

Horz, H.P., Yimga, M.T., \& Liesack, W. (2001). Detection of methanotroph deiversity on roots of submerged rice plants by molecular retrieval of pmoA, mmoX, mxaF, and 16S rRNA and ribosomal polymorphism profiling. Applied and Environmental Microbiology, 67, 4177-4185. http://dx.doi.org/10.1128/AEM.67.9.4177-4185.2001

IPCC. (1994). Climate Change, 1994, Radiative forcing of climate change and an evaluation of the IPCC 1992 
emission scenarios, Cambridge Univ Press.

Ishigaki, T., Yamada, M., Nagamori, M., Ono, Y., \& Inoue, Y. (2005). Estimation of methane emission from whole waste landfill site using correlation between flux and ground temperature. Environmental Geology, 48, 845-853. http://dx.doi.org/10.1007/s00254-005-0008-0

Koh, S.C., Bowman, J.P., \& Sayler, G.S. (1993). Soluble methane monooxygenase production and trichloroethylene degradation by a type I methanotroph, Methylomonas methanica 68-1. Applied and Environmental Microbiology, 59, 960-967.

Koschorreck, M.., Brookland, I., \& Matthias, A. (2003). Biogeochemistry of the sediment-water interface in the littoral of an acidic mining lake studied with microsensors and gel-probes. Journal of Experimental Marine Biology and Ecology, 285-286, 71-84. http://dx.doi.org/10.1016/S0022-0981(02)00520-8

Lane, D.J. (1991). 16S/23S rRNA Sequencing. In: Stackebrandt, Goodfellow M (Eds). Nucleic acid techniques in bacterial systematics. John Wiley \& Sons, Inc, New York, USA

McDonald, I.R., Kenna, E.M., \& Murrell, J.C. (1995). Detection of methanotrophic bacteria in environmental samples with the PCR. Applied and Environmental Microbiology, 61, 116-121.

Picard, C., Ponsonnet, C., Paget, E., Nesme, X., \& Simonet, P. (1992). Detection and enumeration of bacteria in soil by direct DNA extraction and polymerase chain reaction. Applied and Environmental Microbiology, 58, 1717-1722.

Pohland, F.G., \& Al-Yousfi, B. (1994). Design and operation of landfills for optimum stabilization and biogas production, Water Science and Technology, 30(12), 117-124.

Rahman, M.T., Crombie, A., Chen, Y., Stralis-Pavese, N., Bodrossy, L., Meir, P., McNamara, M.P., \& Murrell, J.C. (2011). Environmental distribution and abundance of the facultative methanotroph Methylocella. The ISME Journal, 5, 1061-1066. http://dx.doi.org/10.1038/ismej.2010.190

Ross, J.L., Boon, P.I., Ford, P., \& Hart, B.T. (1997). Detection and quantification with 16S rRNA probes of planktonic methylotrophic bacteria in a foodplain lake. Microbial Ecology, 34, 97-108. http://dx.doi.org/10.1007/s002489900039

Shigematsu, T., Hanada, S., Eguchi, M., Kamagata, Y., Kanagawa, T., \& Kurane, R. (1999). Soluble methane monooxygenase gene clusters from trichloroethylene-degrading Methylomonas sp. strains and detection of methanotrophs during in situ bioremediation. Applied and Environmental Microbiology, 65, 5198-5206.

Sundh, I., Borga, P., Nilsson, M., \& Svensson, B.H. (1995). Estimation of cell numbers of methanotrophic bacteria in boreal peatlands based on analysis of specific phospholipid fatty acids. FEMS Microbiology Ecology, 18, 103-112. http://dx.doi.org/10.1111/j.1574-6941.1995.tb00167.x

Tsien, H.C., Bratina, B.J., Tsuji, K., \& Hanson, R.S. (1990). Use of oligodeoxynucleotide signature probes for identification of physiological groups of methylotrophic bacteria. Applied and Environmental Microbiology, 56, 2858-2865.

Vecherskaya, M.S., Barns, S.M., Pelletier, D.A., \& Lane, D.J. (1993). Activity and species composition of aerobic methanotrophic communities in tundra soils. Current Microbiology, 27, $181-184$. http://dx.doi.org/10.1007/BF01576018

Williams, P.T. (1998). Waste treatment and disposal. John Wiley and Sons, Chichester, England.

Wise, M.G., McArthur, J.V., \& Shimkets, L.J. (1999). Methanotroph diversity in landfill soil: Isolation of novel type I and type II methanotrophs whose presence was suggested by culture independent 16S ribosomal DNA analysis. Applied and Environmental Microbiology, 65, 4887-4897. 
Table 1. PCR primer pairs used in this study

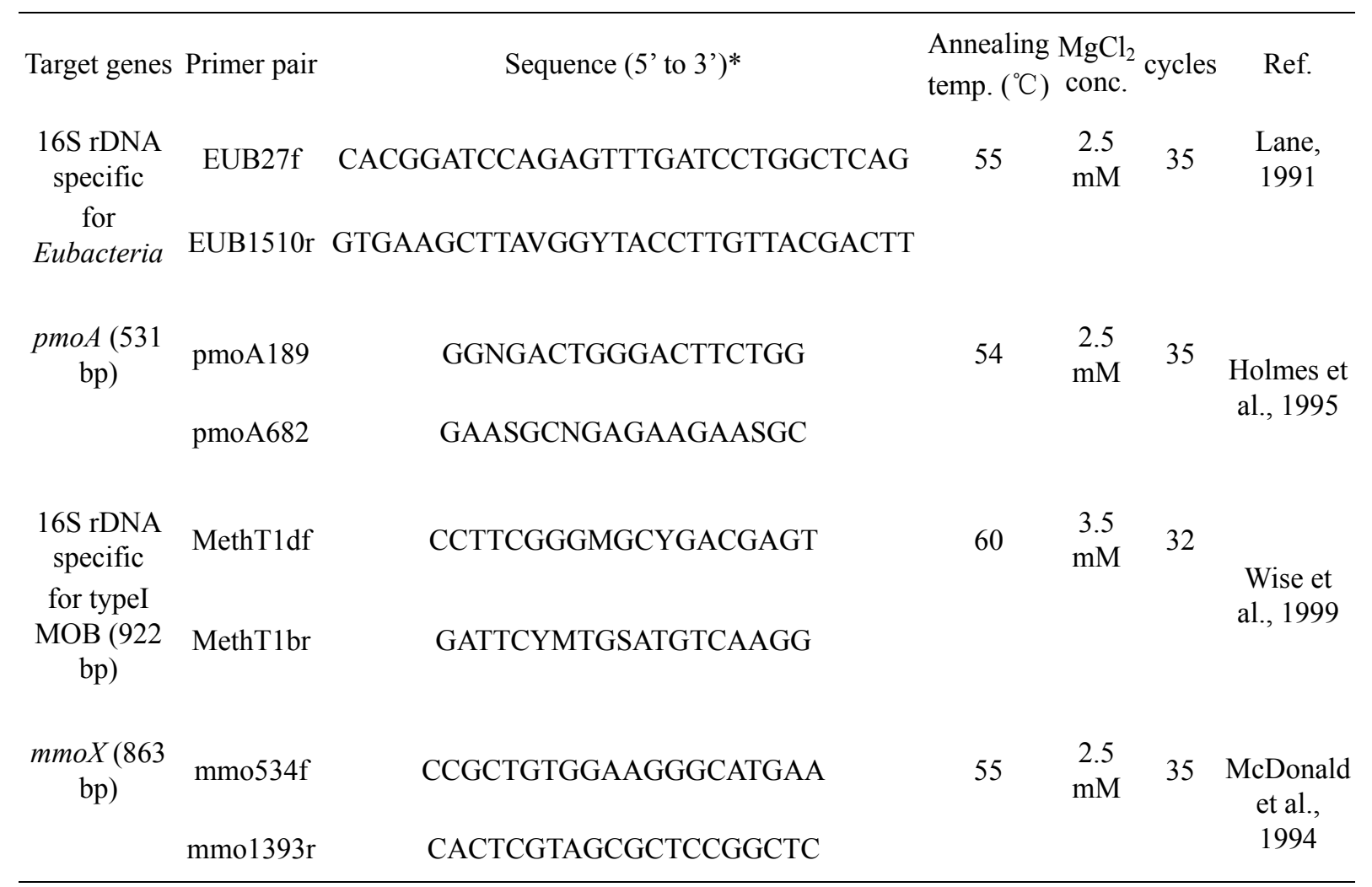

* $\mathrm{N}$ bases $\mathrm{A}, \mathrm{C}, \mathrm{G}$, or T; M bases A or $\mathrm{C}$; $\mathrm{S}$ bases $\mathrm{G}$ or $\mathrm{C}$; $\mathrm{Y}$ bases $\mathrm{C}$ or $\mathrm{T}$.

Table 2. Gas fluxes at the soil sampling points and parameters for the methane oxidation kinetics

\begin{tabular}{|c|c|c|c|c|c|c|c|c|c|c|c|}
\hline \multirow{3}{*}{ soil } & \multicolumn{3}{|c|}{ Gas flux $\left(\mathrm{mmol} \cdot \mathrm{min}^{-1} \cdot \mathrm{m}^{-2}\right)$} & \multirow{2}{*}{\multicolumn{2}{|c|}{$\mathrm{CH}_{4}$ oxidizing activity }} & \multicolumn{3}{|c|}{$\mathrm{K}_{\mathrm{s}}(\mu \mathrm{M})$} & \multicolumn{3}{|c|}{$\mathrm{V}_{\mathrm{m}}\left(\mu \mathrm{mol} \cdot \mathrm{h}^{-1} \cdot \mathrm{g}^{-1}\right)$} \\
\hline & \multirow[b]{2}{*}{$\mathrm{CH}_{4}$} & \multirow[b]{2}{*}{$\mathrm{CO}_{2}$} & \multirow[b]{2}{*}{$\begin{array}{l}\text { Flux ratio } \\
\left(\mathrm{CH}_{4} / \mathrm{CO}_{2}\right)\end{array}$} & & & \multirow{2}{*}{$\begin{array}{c}\text { Simple } \\
\text { kinetics } \\
(0-100,000 \\
\left.\mathrm{ul} \cdot \cdot^{-1}\right)\end{array}$} & \multicolumn{2}{|c|}{$\begin{array}{l}\text { Separate } \\
\text { kinetics }\end{array}$} & \multirow{2}{*}{$\begin{array}{c}\text { Simple } \\
\text { kinetics } \\
(0-100,000 \\
\left.\mathrm{ul} \cdot 1^{-1}\right)\end{array}$} & \multicolumn{2}{|c|}{$\begin{array}{l}\text { Separate } \\
\text { kinetics }\end{array}$} \\
\hline & & & & $\begin{array}{c}\mathrm{CH}_{4} 10 \% \\
\left(\mu \mathrm{mol} \cdot \mathrm{hr}^{-1} \cdot \text { cell }^{-1}\right)\end{array}$ & $\begin{array}{c}\mathrm{CH}_{4} 0.1 \% \\
\left(\mu \mathrm{mol} \cdot \mathrm{hr}^{-1} \cdot \mathrm{cell}^{-1}\right)\end{array}$ & & \begin{tabular}{|c|}
$<$ \\
1,000 \\
$\mathrm{ul} \cdot 1^{-1}$ \\
\end{tabular} & $\begin{array}{c}> \\
5,000 \\
\mathrm{ul} \cdot 1^{-1} \\
\end{array}$ & & \begin{tabular}{|c|}
$<$ \\
1,000 \\
$\mathrm{ul} \cdot 1^{-1}$ \\
\end{tabular} & $\begin{array}{c}> \\
5,000 \\
\mathrm{ul} \cdot 1^{-1}\end{array}$ \\
\hline $\mathrm{A}$ & 5.7 & 0.64 & 8.9 & $1.5 \times 10^{-8}$ & $8.5 \times 10^{-10}$ & & 59 & 730 & & 0.19 & 4.8 \\
\hline $\mathrm{B}$ & $\begin{array}{c}-1.5 \mathrm{x} \\
10^{-2}\end{array}$ & $\begin{array}{c}7.5 \mathrm{x} \\
10^{-2}\end{array}$ & -0.2 & $2.2 \times 10^{-7}$ & $4.9 \times 10^{-8}$ & 61 & & & $3.5 \times 10^{2}$ & & \\
\hline $\mathrm{C}$ & 19 & 1.5 & 13 & $5.4 \times 10^{-8}$ & $2.5 \times 10^{-9}$ & & 940 & 2,600 & & 0.67 & 4.7 \\
\hline $\mathrm{D}$ & $\begin{array}{c}-5.2 \mathrm{x} \\
10^{-3}\end{array}$ & $\begin{array}{c}8.9 \mathrm{x} \\
10^{-2}\end{array}$ & -0.058 & $4.1 \times 10^{-7}$ & $7.6 \times 10^{-8}$ & 490 & & & $3.7 \times 10^{2}$ & & \\
\hline $\mathrm{E}$ & 3.9 & 4.3 & 0.91 & $4.5 \times 10^{-9}$ & $2.7 \times 10^{-10}$ & & 240 & 1,700 & & 0.38 & 2.9 \\
\hline $\mathrm{F}$ & N.D. & N.D. & - & $5.4 \times 10^{-10}$ & $2.4 \times 10^{-10}$ & 370 & & & 0.47 & & \\
\hline
\end{tabular}


Table 3. Kinetic constants of MOB strains isolated from the landfill surface

\begin{tabular}{|c|c|c|c|c|c|}
\hline soils & strain & $\begin{array}{c}\mathrm{Vm} \\
(\mathrm{nmol} / \mathrm{h} / \text { cell })\end{array}$ & $\mathrm{Ks}(\mu \mathrm{M})$ & $\begin{array}{l}\text { True first order } \\
\text { kinetic constant }\end{array}$ & $\begin{array}{l}\text { pseudo first } \\
\text { order kinetic } \\
\text { constant }\end{array}$ \\
\hline \multirow[t]{4}{*}{ A } & AH522 & $2,4 \times 10^{-4}$ & 357 & & 0.67 \\
\hline & AH528 & $7.6 \times 10^{-4}$ & 6050 & & 0.13 \\
\hline & AH521 & & & 0.48 & \\
\hline & AH524 & & & 0.41 & \\
\hline \multirow[t]{10}{*}{ B } & BL109 & $1.6 \times 10^{-4}$ & 1790 & & 0.090 \\
\hline & BH502 & $1.0 \times 10^{-4}$ & 232 & & 0.44 \\
\hline & BH508 & $1.2 \times 10^{-3}$ & 3810 & & 0.32 \\
\hline & BH510 & $7.8 \times 10^{-4}$ & 4390 & & 0.18 \\
\hline & BH514 & $7.8 \times 10^{-5}$ & 631 & & 0.12 \\
\hline & BX531 & $5.6 \times 10^{-5}$ & 974 & & 0.057 \\
\hline & BL102 & & & 2.10 & \\
\hline & BL105 & & & 0.48 & \\
\hline & BL108 & & & 1.04 & \\
\hline & BH504 & & & 0.19 & \\
\hline \multirow[t]{12}{*}{$\mathrm{C}$} & CL101 & $9.1 \times 10^{-4}$ & 4840 & & 0.19 \\
\hline & CL104 & $1.7 \times 10^{-4}$ & 352 & & 0.47 \\
\hline & CH511 & $1.9 \times 10^{-4}$ & 2060 & & 0.090 \\
\hline & CH514 & $2.2 \times 10^{-4}$ & 11600 & & 0.019 \\
\hline & CH516 & $3.3 \times 10^{-4}$ & 4410 & & 0.076 \\
\hline & CH523 & $7.6 \times 10^{-4}$ & 2370 & & 0.32 \\
\hline & CH525 & $1.2 \times 10^{-2}$ & 39500 & & 0.30 \\
\hline & CX531 & $6.8 \times 10^{-4}$ & 12300 & & 0.055 \\
\hline & CL102 & & & 0.067 & \\
\hline & CH518 & & & 5.60 & \\
\hline & CH521 & & & 2.90 & \\
\hline & CH522 & & & 0.82 & \\
\hline \multirow[t]{7}{*}{$\mathrm{D}$} & DH501 & $6.4 \times 10^{-5}$ & 247 & & 0.26 \\
\hline & DH502 & $5.7 \times 10^{-5}$ & 24.7 & & 2.32 \\
\hline & DH507 & $3.5 \times 10^{-4}$ & 1280 & & 0.28 \\
\hline & DH519 & $6.1 \times 10^{-5}$ & 152 & & 0.40 \\
\hline & DH520 & $5.6 \times 10^{-4}$ & 1440 & & 0.39 \\
\hline & DH521 & $4.1 \times 10^{-5}$ & 96.2 & & 0.42 \\
\hline & DH522 & $8.8 \times 10^{-5}$ & 61.0 & & 1.45 \\
\hline
\end{tabular}


A

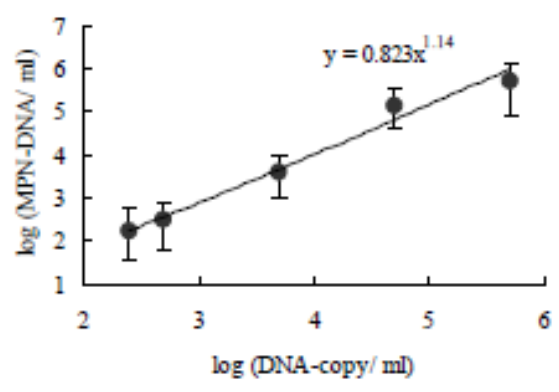

B
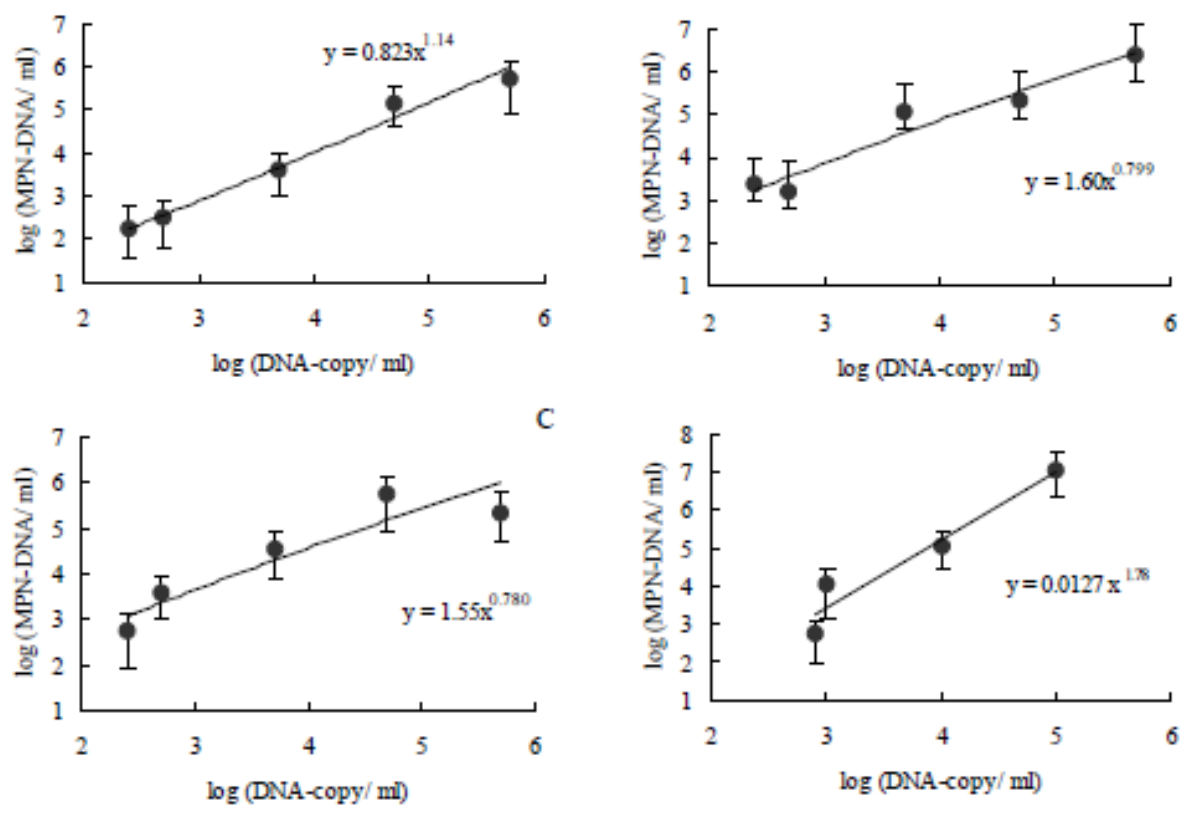

C

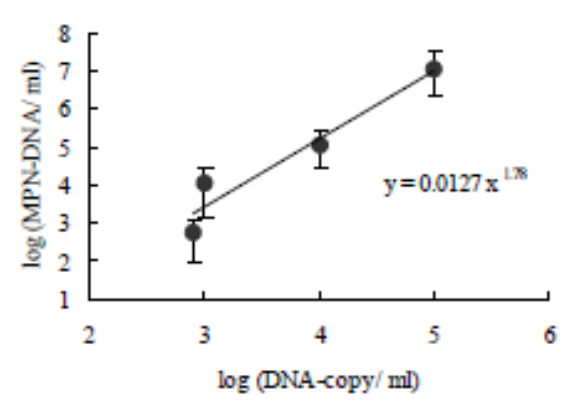

Figure 1. Validation of MPN-PCR assays of the eubacterial 16S rDNA (A), pmoA (B), type- I specific 16S rDNA (C), $\operatorname{mmoX}(\mathrm{D})$

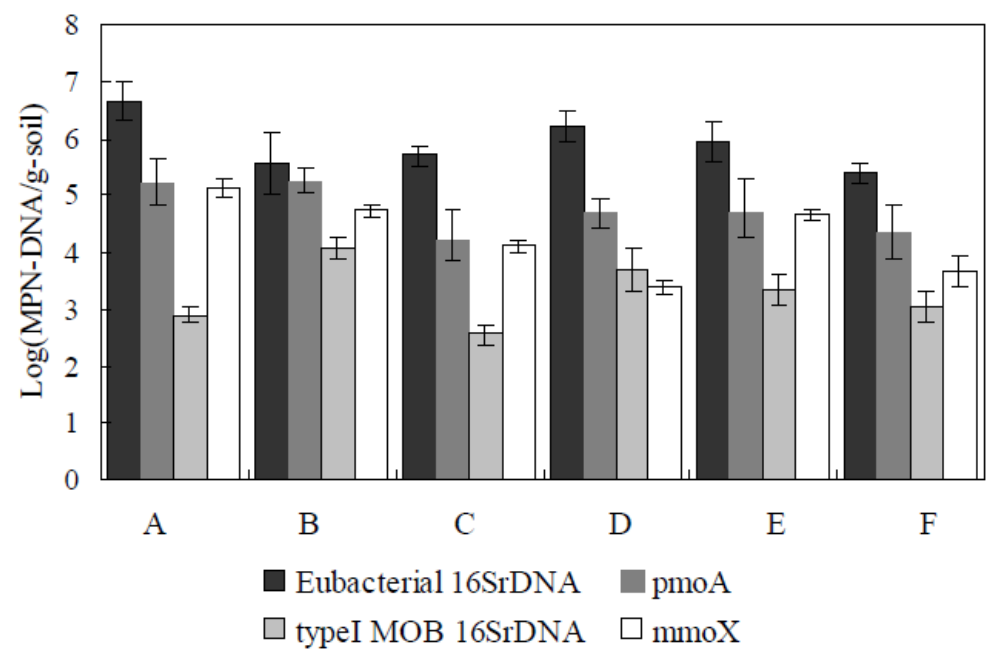

Figure 2. MOB community analysis using gene markers as a measure of each group of bacteria 